\title{
Collection Development from a College Perspective: A Comment and a Response
}

Editor's Note: We are pleased to present below a comment on the preceding article prepared by Evan I. Farber, Librarian, Earlham College, Richmond, Indiana. A response by William Miller, one of the authors of the article, follows.

EVAN I. FARBER

\section{A COMMENT}

To

BEGIN WITH, I agree fully with the main thrust of the article-that the approach to building a college library's collection must be very different from that for a university library and that it is really the college librarian's responsibility, not the faculty's, to ensure the collection's usefulness. I do, however, have several reservations about specific points.

1. Periodical collections "should, for the most part, reflect the titles covered in the major indexing tools the library receives."

To be sure, whether or not a periodical is indexed should be an important consideration, but it is also important to have as many of those titles as possible that are important for supporting course work. Restricted to indexed periodicals, most college libraries would not consider subscribing to Paris-Match or Der Spiegel, for example, because they're not in the generally available indexes, even though students taking French or German should be able to see them.

A periodical not covered by the indexes needs to be examined very carefully for possible subscription, but should not be eliminated from consideration on that basis alone. The reason its being indexed is important, of course, is because that makes its use more likely. If other factors, such as class assignments or even student browsing, ensure its use, whether or not it's indexed is not as important.

There's another reason for not using indexing as a primary goal. It takes a while for any new periodical to get into an indexand that is particularly true, of course, of the Wilson indexes, for which inclusion of particular titles is determined by subscribers' votes. I think, however, that a college librarian has a responsibility for adding new periodicals-not constantly or hastily, but judiciously, with as much or more care than is given to book selection.

Among the titles our library has added within the past year are some not covered yet by any index, but I can defend the selection of each of them on some other basis of selection: Omni, Grants Magazine, Asia, Bennington Review, Public Opinion, and the Cornell Review. In a few years they probably will be indexed, but it's up to librarians to make sure that students do find out about them before then. Encouraging students to read, to browse, to become familiar with new books and periodicals is part of a college librarian's responsibility, and what the indexing services have chosen to cover cannot obviate that.

2. Another objection stems from the authors' overemphasis on bibliographic instruction, their claim that it should be the most important criterion in determining additions to the collection. Now this may 
seem a strange comment from one who is so closely identified with bibliographic instruction, and I'm sure our agreements about it are more numerous and important than our differences. But the suggestion that "departments which have resisted bibliographic instruction should very properly have their book budgets cut" simply runs counter to what I think is the desirable, even necessary, approach to bibliographic instruction.

Such a punitive device will hardly engender that spirit of cooperation, that sense of common endeavor between teaching faculty and librarians that is the sine qua non for an ongoing program of bibliographic instruction. It's too easy to forget that bibliographic instruction is not an end in itselfits justification and primary purpose are the enhancement of the teaching/learning process. Together with teaching faculty, we college librarians are in the business of education and regarding and approaching bibliographic instruction as an end in itself, without considering its educational context, can only be counterproductive and result in an unsupported and eventually dismantled program.

I think that one source of the authors' error here is their implicit assumption that all teaching has the same thrust, that bibliographic instruction can be equally useful for all disciplines, or even for all types of teaching. For example, after all these years, I still find it difficult to relate bibliographic instruction to mathematics courses or to foreign-language courses that emphasize language skills. One might respond that, okay, then these departments don't need much library support, but that's very different from saying that they should "have their book budgets cut."

Librarians must understand and appreciate that there are many approaches to teaching, and not every one, not even some of the most successful ones, entail use of the library. To be sure, we believe that good teaching can be made even better if students are required to use the library and are given instruction in that use, but that does not extend to every course.

We need to respect the different approaches to pedagogy and work with those that are appropriate for bibliographic in- struction. Our creativity and energy should be focused on the teaching faculty with whom we can work-there's enough to be done just with them. Penalizing others will only put faculty on the defensive and ruin a working relationship that was probably fragile enough to begin with.

3. Librarians "should secure control of the acquisitions budget, if they do not already have it. ... While the faculty may know their subjects, they probably know little about how students use the library, and their judgment as book selectors is questionable."

I'm not quite sure what Miller and Rockwood mean by "secure control," and if they mean the librarian is responsible for allocating the budget and supervising its expenditure over the fiscal year, I cannot argue with that. But if, on the other hand, they mean (and this is what I think they do mean) that the librarian should initiate all ordering or at least have to approve every request, I can't agree.

First of all, it's not wise politically and will surely test the fragility of that relationship I spoke of earlier. More important, though, it assumes that librarians know more about the content of disciplines than most do, or even more than they should be expected to know. It is unfair to categorize faculty members (even with a qualified "too often") as "lacking in their knowledge of books, disinterested in books ... prone to selecting only narrow research works on the one hand or textbooks on the other." My experience is that the few faculty members who fit that description will not even bother to order, and then the librarian can fill that gap.

It is more likely that most faculty members can't be depended upon to maintain some sort of balance in the library's collection, but that is where the librarian comes in: to suggest titles for filling in gaps and, more important, to work with faculty and help them develop a wider perspective. The library collection is not an end in itself: It exists primarily to support the teaching program, and teachers should be interested in making sure the collection does that. If they do not, then it's up to the librarian, but he or she should always be conscious of faculty expertise and responsibility. 
WILLIAM MILLER

\section{A RESPONSE}

$\mathbf{W}$ E APPRECIATE Evan Farber's thoughtful critique, which gives us an opportunity to clarify several matters. Farber senses, quite rightly, that our article is somewhat rigid and doctrinaire. It is so because we were attempting to define some theoretical, objective criteria and then explore what the logical consequences of these criteria might be, ignoring for the moment the political and social context in which the library exists. In real life, of course, we do not ignore the political and social context, and as a result we end up behaving very much as Farber suggests that we should.

Nevertheless, we thought it valuable to theorize, with this question in mind: "If I were not running the risk of offending department $X$, and if I did not need to do a favor for professor $\mathrm{Y}$, what objective criteria could I apply to my acquisitions process, to provide maximum educational benefit to the greatest number of students, given a budget which does not allow me to purchase everything I want?"

This question is complex and frustrating, so much so that many college librarians refuse to accept its legitimacy, preferring instead to follow whims, hunches, and prejudices, and to bemoan the inevitably insufficient budget.

A second group of college librarians acknowledges the question but says, in effect, "Although we cannot order everything, which every faculty member might theoretically want, we can and will order anything any faculty member actually does request." We see little difference between the first and second responses; in both cases, librarians are refusing to make professional judgments.

We suggest a third response: "Although I have the money to order any particular item and could order it if I wanted to, I do not want to unless it fits into a collection development policy built around an objective set of criteria, which I have already defined." With that third response in mind, we should like to respond to Farber's three specific reservations.
1. In emphasizing that periodical collections should reflect titles covered in indexing tools, we acknowledge we are out on a limb and would like to address important questions he raises.

There are many thousands of fine periodicals, all of them potentially useful for course work. But which ones will students actually use? Clearly, they will almost always use the most highly indexed periodicals, because indexing provides their most important subject access. There are, of course, bibliographies that students might use, and they may be introduced to periodicals in several other ways. But how can one rationally build a small periodicals collection based on these other ways? On the other hand, we know for certain that students will be using the periodicals suggested to them in Readers' Guide and the other more common indexes.

We have no wish to make demigods out of the people at $\mathrm{H}$. W. Wilson, and we recognize that there are other bases on which to collect periodicals, but they are weaker, more subjective, and too dependent on individual needs that may be transitory. Therefore, for small academic libraries, we have no hesitation about calling the acquisition of highly indexed periodicals the primary task in the development of the collection, assuming that the primary goal of collecting is use, and not the creation of that mythical budget-eating monster, the "balanced collection."

Der Spiegel illustrates our point well. Any large academic library should have it, and any small academic library should have it, if it is actually playing a part in the instructional program. But we would hate to see a library of 700 or 1,000 periodical titles subscribing to Der Spiegel simply because someone believes that it is the most important German newsmagazine, something that one "must" have. We would ask librarians at such an institution: "As far as you can tell, do any students actually use it?" "Is there any faculty member who seriously (and not just wishfully) supports the subscription as an aid to the instructional program, or who expects students to use it?" If the answers are "no" on both counts, then the subscription should be cancelledunless there is a political consideration that 
outranks one's normal criteria. Certainly, after cancellation, there may be an occasional person who asks for Der Spiegel. But how many students ask, every day, for more common titles that the library cannot supply?

2. Perhaps we were too insistent about library instruction. We do counsel an aggressive instruction program, but Farber is right to make a distinction between departments that are noncooperative and those that simply cannot accommodate library work into the structure of their courses. A hostile attitude toward either kind of department is certainly inappropriate and self-defeating.

We like Farber's distinction between consulting with departments about their reduced need for support rather than telling them that their budgets are being cut. The difference can certainly be substantive as well as semantic and political. At the same time, it is also appropriate to make special efforts to enrich the collections in those areas where bibliographic instruction has created increased demand.

3. By "securing control of the acquisitions budget," we meant that librarians should apportion a large part of the acquisitions budget among departments, expecting departments to initiate the bulk of their own book ordering, but standing ready, not only to expend departmental funds, but also to exercise judgment on all departmental orders.

We do think that librarians should reserve the right to approve every request, but this does not mean imperious, arbitrary action; it means questioning and negotiating requests that seem too specialized, too expensive, too redundant, or otherwise inappropriate. We think also that librarians should retain approximately 25 percent of the budget for discretionary buying. Here, and in their control of the departmental funds, librarians would be exercising their professional judgments. 